University of Michigan Law School

University of Michigan Law School Scholarship Repository

Law \& Economics Working Papers

$5-1-2012$

\title{
Launching the Insider Trading Revolution: SEC v. Capital Gains Research Bureau
}

Adam C. Pritchard

University of Michigan Law School, acplaw@umich.edu

Follow this and additional works at: https://repository.law.umich.edu/law_econ_current

Part of the Law Commons

Working Paper Citation

Pritchard, Adam C., "Launching the Insider Trading Revolution: SEC v. Capital Gains Research Bureau" (2012). Law \& Economics Working Papers. 68.

https://repository.law.umich.edu/law_econ_current/68

This Article is brought to you for free and open access by University of Michigan Law School Scholarship Repository. It has been accepted for inclusion in Law \& Economics Working Papers by an authorized administrator of University of Michigan Law School Scholarship Repository. For more information, please contact mlaw.repository@umich.edu. 


\title{
Launching the Insider Trading Revolution: SEC v. Capital Gains Research Bureau
}

\author{
A.C. Pritchard \\ University of Michigan Law School
}

Securities and Exchange Commission v. Capital Gains Research Bureau, Inc. ${ }^{1}$ marked the resurgence of the SEC in the Supreme Court, sparking a decade-long winning streak there. The Capital Gains decision, although turning on an interpretation of the Investment Advisers Act of $1940,{ }^{2}$ also gave the green light to the SEC to push the boundaries of its power in other areas. Moreover, Capital Gains suggested that the SEC could expand its power through agency and judicial interpretation of existing statutes and regulation, without resorting to the cumbersome rulemaking process under the Administrative Procedure Act, or still more daunting, seeking legislation. After its victory in Capital Gains, the SEC would push an aggressive interpretation of $\S 10$ (b) of the Exchange Act in the lower courts, particularly the Second Circuit, to crack down on insider trading. This Chapter uncovers the seeds of the SEC's insider trading crusade in Capital Gains and how that opinion influenced subsequent securities jurisprudence.

I proceed as follows. Section I provides background on the SEC and its relationship with the Supreme Court prior to Capital Gains. Section II follows the SEC’s Capital Gains enforcement action as it made its way up through the district court and the

${ }^{1} 375$ U.S. 180 (1963).

${ }^{2} 54$ Stat. 847, as amended 15 U.S.C. § 80b-1 et seq. 
Second Circuit. Section III explores how the case unfolded in the Supreme Court. Section IV then assesses Capital Gains’ long-term impact. A brief Conclusion follows.

\section{Background}

A generation before the Capital Gains decision, the fledgling SEC had put itself at the center of the nation's political discourse. A voting public weary of the deprivation and misery of the Great Depression cheered as the SEC went after the Wall Street fat cats. William O. Douglas catapulted to national prominence during the New Deal as chairman of the SEC by bringing the New York Stock Exchange to heel in the wake of Richard Whitney scandal. ${ }^{3}$ The SEC stayed in the headlines during its long fight to dismantle the giant public utility empires under the mandate of the Public Utility Holding Company Act ("PUHCA”). The agency enjoyed an enviable record of success in the high court, losing only two out of thirteen PUHCA cases decided; ${ }^{4}$ overall, the agency lost only three cases out of twenty-five between 1936 and $1955 .^{5}$ After the Supreme Court decided the last of that string of PUHCA cases, the SEC's involvement in cases at the

${ }^{3}$ Bruce Allen Murphy, Wild Bill 136-154 (2003).

${ }^{4}$ SEC v. Chenery (Chenery I), 318 U.S. 80 (1943); American Power and Light Co. v. SEC, 325 U.S. 385 (1945). The Chenery I defeat was essentially undone by the Court four years later when the case returned to the Court. SEC v. Chenery (Chenery II), 332 U.S. 194 (1947). Engineers Public Service v. SEC, 332 U.S. 788 (1947), was rendered moot by a settlement.

5 The SEC's additional loss was Jones v. SEC, 298 U.S. 1 (1936). This decision pre-dated Franklin Delano Roosevelt's New Deal transformation of the Court. 
Court took a marked decline. The Court decided only three securities cases of any kind between 1956 and 1960; two of those were per curiam. ${ }^{6}$

That dearth of securities litigation reflected the SEC's diminished role. ${ }^{7}$ By the 1950s, the public utilities had been brought low and the campaign to tame Wall Street was a rapidly fading memory. The SEC was no longer the prominent political actor that it had been in the 1930s under the leadership of Douglas. World War II, which saw government and business join hands in the effort to defeat the totalitarian threats of Germany and Japan, reduced the SEC to a political afterthought. The agency, deemed "non-essential” to the war effort, saw itself downsized and exiled to Philadelphia, not to return to Washington until 1948. The agency's return from exile did not signal a return to relevance. The Truman and Eisenhower administrations had other political priorities, and the SEC Chairmen appointed by those presidents were not fueled by the ambition that had driven Douglas in that role a generation earlier.

The 1960s - and the election of John F. Kennedy - marked the beginning of a new era for the administrative agencies and a rejuvenated SEC. Kennedy called on James Landis - a New Deal SEC chairman - to draft a report outlining reforms for the administrative agencies. ${ }^{8}$ Landis urged that more money be allocated to the SEC, but more generally, he called for rejuvenated leadership by "gradually restaffing [the

${ }^{6}$ SEC v. La. Pub. Ser. Comm'n, 353 U.S. 368 (1957) (per curiam); SEC v. Variable Annuity Life Ins., 359 U.S. 65 (1959); Dyer v. SEC, 359 U.S. 499 (1959) (per curiam).

${ }^{7}$ See generally Joel Seligman, The Transformation of Wall Street 241-289 ( ${ }^{\text {rd }}$ Ed. 2003).

${ }^{8}$ James M. Landis, Report on Regulatory Agencies to the President-Elect (December 1960). 
agencies] with men who, because of their competence and their desire to fulfill the legislative mandates described in the basic statutes establishing these agencies, will inspire a sense of devotion to and pride in the public service by their many employees."9

At the SEC, the new leadership called for by Landis came in the form of William Cary. The Columbia corporate law professor was Kennedy's second choice, called upon after Harvard's Louis Loss, the dean of securities scholars, had turned Kennedy down. ${ }^{10}$ Despite being Kennedy's second choice, Cary had strong links to the SEC’s New Deal glory days: Cary had been a student in one of Professor William O. Douglas's last corporate finance classes, and he later went to work for Chairman Douglas at the SEC. ${ }^{11}$

Things were going to happen at the SEC on Cary’s watch; Cary signaled his intent to push the agency in a more activist direction shortly after his arrival. Cary's opinion for the Commission in Cady, Roberts \& Co. ${ }^{12}$ announced in unmistakable fashion the agency's newfound commitment to interpreting broadly its statutory mandate. In Cady, Roberts, the Commission interpreted Rule 10b-5 of the Exchange Act to prohibit insider trading. Rule 10b-5 had been adopted by the Commission three decades earlier under its $\S 10$ (b) authority as a general anti-fraud prohibition, but the rule (and statute) makes no mention of insider trading. Notwithstanding this omission, the SEC found in Cady, Roberts that the partner of a brokerage firm had violated Rule $10 \mathrm{~b}-5$ when he traded on

${ }^{9}$ Id. at 1 . Of direct relevance to Capital Gains, Landis called for greater regulation of investment advisers, "many of whom have morals not exceeding those of tipsters at the race track." Id. at 33.

${ }^{10}$ Seligman, supra note 7, at 291.

11 Id. at 293.

1240 SEC 907 (1961). 
non-public information. The partner had learned, in his role as a director of a public company, that the company was planning to cut the size of its dividend. In concluding that the partner had violated Rule 10b-5, Cary set out a broad standard for the insider trading prohibition:

The obligation rests on two principal elements; first, the existence of a relationship giving access, directly or indirectly, to information intended to be available only for a corporate purpose and not for the personal benefit of anyone, and second, the inherent unfairness involved where a party takes advantage of such information knowing it is unavailable to those with whom he is dealing. ${ }^{13}$

These elements are conspicuously absent from the text of either Rule $10 \mathrm{~b}-5$ or $\S 10(\mathrm{~b})$. Cary gave notice that in interpreting "the[] elements [of $\S 10(\mathrm{~b})$ ] under the broad language of the anti-fraud provisions we are not to be circumscribed by fine distinctions and rigid classifications." 14 Thus, Cary announced the SEC's intent to root out information asymmetries in the secondary markets to protect "the buying public" "from the misuse of special information.”15 The securities laws would be interpreted as needed to achieve that goal; statutory literalism would not be an impediment. But Cary's broad vision of the SEC's authority had not yet been validated by a court. The respondents in Cady, Roberts did not seek review of the agency's order, so it remained to be seen whether Cary’s novel interpretation of § 10(b) would withstand judicial scrutiny.

There were potential landmines waiting for the SEC's insider trading initiative. Just a month after the SEC handed down Cady, Roberts the SEC argued before the

${ }^{13}$ Id. at 912 (footnote omitted).

${ }^{14} \mathrm{Id}$.

${ }^{15}$ Id. at 913. 
Supreme Court in Blau v. Lehman. ${ }^{16}$ Blau involved the interpretation of the "short-swing” profits rule of $\S 16(\mathrm{~b})$ of the Exchange Act. Despite the focus on insider trading during the hearings that led to the adoption of the Exchange Act, § 16(b) is the only Exchange Act provision, as it was adopted by Congress in 1934, that deals explicitly with insider trading.

The facts of Blau bore some similarities to Cady, Roberts. At issue was whether the knowledge of a Lehman Brothers partner, Thomas, who was serving as a director of a public company, Tide Water, could be attributed to the investment bank. ${ }^{17}$ If Lehman was charged with Thomas's knowledge, then the bank's profits from trading in Tide Water's stock would be subject to disgorgement. The district court found that Thomas had not shared his knowledge of Tide Water's affairs with his Lehman partners. ${ }^{18}$

The Second Circuit affirmed the decision over the dissent of Judge Charles Clark. ${ }^{19}$ Clark plays a central role in our tale, and his background suggested that he would be predisposed to the SEC's arguments. Clark was the former dean of the Yale Law School, where he had been a colleague of William O. Douglas. Clark, like Douglas, was a committed New Dealer. ${ }^{20}$ Moreover, he had worked for the SEC part time for a brief

${ }^{16} 368$ U.S. 403 (1962).

${ }^{17}$ Id. at $404-406$.

${ }^{18} \mathrm{Id}$. at 407.

${ }^{19}$ Blau v. Lehman, 286 F.2d 786 ( $2{ }^{\text {nd }}$ Cir. 1960), and id. at 793 (Clark, J., dissenting).

${ }^{20}$ Clark was best known as the architect of the Federal Rules of Civil Procedure, which had been adopted in 1938 when Clark was serving as the head of the Federal Rules Advisory Committee. Charles E. Clark, The New Federal Rules of Civil Procedure: The Last Phase-Underlying Philosophy Embodied in Some of the Basic Provisions of the New Procedure, 23 A.B.A. J. 976 (1937). 
period at Douglas's behest. ${ }^{21}$ The two remained friends ${ }^{22}$ notwithstanding a falling out when Douglas persuaded Clark to endorse Roosevelt’s Court-packing plan while Douglas remained silent. ${ }^{23}$ In fact, Clark had hoped that Douglas would succeed him as dean at Yale, but that hope was dashed by Douglas's appointment to the Supreme Court. ${ }^{24}$ Clark’s judicial philosophy, like Douglas’s, allowed plenty of room for judges to chart a novel course: "We need the unprincipled decision, i.e., the unprecedented and novel decision ... to mark judicial progress."25

Clark’s Blau dissent stressed that the courts should defer to the SEC. When the case was initially decided, he fretted that the SEC's views were not solicited. ${ }^{26}$ After the decision came down, the SEC petitioned for leave to participate as amicus and to file a petition for rehearing, and Clark lobbied hard to have the case heard. ${ }^{27}$ When the petition was denied, Clark was nearly apoplectic. He complained that the majority's opinion "leaves this important area of the law almost ludicrously uncertain. ... My own criticisms

${ }^{21}$ Seligman, supra note 7 , at 111.

${ }^{22}$ William O. Douglas, Charles E. Clark, 73 Yale L.J. 3, 3 (1963).

${ }^{23}$ Murphy, supra note 3, at 129.

${ }^{24}$ Letter from Charles Clark to Arthur B. Darling, (3/20/39), Charles E. Clark Papers, Series I, Box 1, Folder 2, Yale University Library, Manuscripts and Archives (hereinafter Clark Papers) ("There was one blow to my plans which came in today when bill Douglas was named to the Supreme Court, for I had expected, as seemed rather likely, that he would succeed me as dean.”). In this same letter, Clark was rather prescient in predicting that Douglas would chafe under the confines of the bench. Id. ("Douglas is one of the ablest and sincerest persons I know, and it is a grand thing to have so young and vigorous a person on the bench, unless indeed one believes that could have done more elsewhere. ... It is hard to think of so vigorous a personality as Douglas confined so young.”).

${ }^{25}$ Charles E. Clark, A Plea for the Unprincipled Decision, 49 Va. L.Rev. 660, 665 (1963).

${ }^{26}$ Blau, 286 F.2d at 796 (Clark, J., dissenting) ("[I]t would seem to me that at least before we dispose of this vastly important issue we should ask the S.E.C. for its informed comments.”).

${ }^{27}$ Memo of Charles Clark to J.E.L., S.R.W., L.P.M., H.J.F., J.J.S., (1/13/1961), Clark Papers, Series II, Box 45, Folder 186, ("May I suggest that, even if some of our colleagues do not want the real help the Commission can give here, I do feel some surprise and chagrin that they are willing to prevent those who do from receiving it.”). 
uttered in my dissent have remained unanswered and have now, as is apparent, the support of the S.E.C.”28 Worse yet, the Second Circuit's rule built "unfair discrimination” “into an important remedial statute-a discrimination substantially eliminating the great Wall Street trading firms from the statute’s operations."29

Clark’s populist tone evidently struck a chord with the Supreme Court, as seven justices voted to grant certiorari. ${ }^{30}$ When Blau came to the Supreme Court, the SEC, alongside its allies in the plaintiffs' bar, urged that $\S 16(\mathrm{~b})$ be read broadly "on policy grounds." ${ }^{31}$ According to the SEC, Thomas's knowledge should be attributed to the partnership and Lehman Brothers "should be held liable even though it is neither a director, officer, nor a 10\% stockholder.” 32 The agency’s argument was weakened, however, by its concession "that such an interpretation is not justified by the literal language of $\S 16(\mathrm{~b})$. " 33 The Court noted the breadth of the SEC's argument: “The argument of ... the Commission seems to go so far as to suggest that $\S 16(\mathrm{~b})$ 's forfeiture of profits should be extended to include all persons realizing 'short swing' profits who either act on the basis of 'inside' information or have the possibility of 'inside'

${ }^{28} \mathrm{Blau}, 286$ F.2d at 799 (Clark, J., dissenting from denial of rehearing in banc).

${ }^{29}$ Id.

${ }^{30}$ Blau v. Lehman, No. 66, Docket Sheet (April 21, 1961) (“Grant: All but Stewart and Black who voted to deny."), Earl Warren Collection, Box 375, Library of Congress.

${ }^{31} \mathrm{Blau}, 368$ U.S. at 410.

${ }^{32}$ Id. at $410-411$.

${ }^{33}$ Id. at 411. 
information.”34 Shades of Cady, Roberts? The SEC's preferred construction would have broadened § 16(b) to make it a general prohibition against insider trading.

The Court, while acknowledging the SEC’s “persuasive policy arguments that the [Exchange] Act should be broadened in this way to prevent 'the unfair use of information' more effectively," declined the SEC's invitation to ignore $\S 16$ 's language. ${ }^{35}$ Amending the statute, according to the Court majority, was not its job: “Congress can and might amend § 16(b) if the Commission would present to it the policy arguments it has presented to us, but we think that Congress is the proper agency to change an interpretation of the Act unbroken since its passage, if the change is to be made. ${ }^{36}$ In other words, lofty policy goals would not allow an end run around plain statutory text. The Court insisted on adherence to the statutory text despite an impassioned dissent from the Court's resident securities expert, Justice Douglas, who echoed Clark’s moralistic tone. Douglas complained that the majority had "sanction[ed], as vested, a practice so notoriously unethical as profiting on inside information." ${ }^{37}$ For the SEC, the Blau opinion offered scant hope that the Supreme Court would be receptive to the free-ranging method of statutory interpretation deployed by Chairman Cary in Cady, Roberts.

II. The district court and Second Circuit

\footnotetext{
${ }^{34}$ Id.

${ }^{35} \mathrm{Id}$.

${ }^{36}$ Id. at 413.

${ }^{37}$ Id. at 414 (Douglas, J., dissenting)
} 
The SEC had not yet launched its campaign against insider trading when it brought an enforcement action against Capital Gains Research Bureau, Inc. and its owner, Harry P. Schwarzmann. ${ }^{38}$ The facts of the case placed it in the nebulous area between pure omissions and misleading half-truths. Capital Gains published a newsletter, “Capital Gains Report,” which it distributed to approximately 5,000 subscribers. The newsletter highlighted a number of stocks in each issue, generally predicting an increase in price. ${ }^{39}$ The SEC alleged that on a number of occasions the defendants had purchased shares in the companies recommended in advance of the distribution of the newsletter. ${ }^{40}$ The stocks increased in price and trading volume after the distribution of the newsletter and Capital Gains liquidated its positions within a week or two thereafter. ${ }^{41}$ The SEC argued that the failure by Capital Gains to disclose its purchases and subsequent sales violated § 206 of the Investment Advisers Act, which makes it unlawful (1) "to employ any device, scheme or artifice to defraud any client or prospective client" or (2) "to engage in any transaction, practice, or course of business which operates as a fraud or deceit upon any client or prospective client." ${ }^{42}$

The district court denied the SEC's motion for a preliminary injunction, concluding that § 206(1) and (2) used "the words 'fraud' and 'deceit' ... in their technical

${ }^{38}$ A detailed history of the enforcement action can be found in Arthur Laby, SEC v. Capital Gains Research Bureau and the Investment Advisers Act of 1940, 91 B.U. L.Rev. 1051, 1056-59 (2011).

${ }^{39}$ Capital Gains, 375 U.S. at 182-183.

${ }^{40}$ SEC v. Capital Gains Research Bureau, Inc., 300 F.2d 745, 747 (2 ${ }^{\text {nd }}$ Cir. 1961). In one case, Capital Gains had sold short the shares of a company that received a negative recommendation

${ }^{41}$ Id.

${ }^{42} 15$ U.S.C. § 80b-6(1) \& (2). 
sense." 43 The trial court's use of the word "technical” would come to have important implications. What did the court mean by "technical”? Apparently, something close to common law notions of deceit. For $\S 206(2)$ to be satisfied, the SEC would have to show that Capital Gains’ clients had lost money as a result of Capital Gains’ sales. For $\S$ 206(1), to be satisfied, the SEC would have to show that Capital Gains intended to cause its clients loss. ${ }^{44}$ The district court's discussion ignores the possibility that a fiduciary duty might give rise to a duty of disclosure, i.e., equitable notions of fraud like those found in the SEC’s Cady, Roberts decision. Instead, the district court read $\S 206$ as incorporating traditional common law notions of fraud involving material misrepresentations.

The SEC appealed to the Second Circuit. In a case in which the agency was pushing the boundaries of its authority, the panel it drew did not bode well. The panel consisted of two Eisenhower appointees, Leonard Moore and Sterry Waterman, ${ }^{45}$ and the lone bright spot for the SEC, Charles Clark, the dissenter in Blau.

Judge Moore wrote the opinion for the panel upholding the district court's denial of the injunction. ${ }^{46}$ The SEC won a minor victory with the court's holding that the district court was wrong in requiring the SEC to show actual losses to investors, necessarily rejecting the narrowest version of common law fraud in interpreting $§ 206$. Nonetheless,

${ }^{43}$ SEC v. Capital Gains Research Bureau, Inc., 191 F. Supp. 897 (1961).

${ }^{44}$ Id. at 899.

${ }^{45}$ Federal Judicial Center, History of the Federal Judiciary, available at www.fjc.gov.

${ }^{46}$ Capital Gains, 300 F.2d at 746, 751. 
the majority opinion appeared to require an affirmative misrepresentation by the defendant, not simply secret profits: "The test is not gain or loss. It is whether the recommendation was honest when made." ${ }^{47}$ How could the court determine if the recommendation was honest? As Moore wrote to his colleagues, "the advice may be tainted with self-interest, but such a fact cannot be assumed or inferred. It must be established by proof such as deliberate misstatements of fact or belief that a stock had a dismal rather than bright future." ${ }^{48}$ A dishonest recommendation would be actionable under $\S 206$, but undisclosed actions would not be actionable, as long as those actions were not inconsistent with that recommendation.

Were Capital Gains’ purchases and sales inconsistent with its recommendations? The SEC urged that "the failure to disclose to clients to whom purchase was recommended that they (defendants), too, had made purchases, constituted a scheme to defraud by failing to disclose a material fact." 49 What was the material fact? The SEC argued that Capital Gains "advice to buy was dishonest and fraudulent” because it failed to disclose the advisers' intention to sell its stock in the near future. ${ }^{50}$ This characterization of the SEC's allegation sounds in misleading omission; there is no mention of fiduciary duty here.

${ }^{47}$ Id. at 749.

${ }^{48}$ Memorandum of LPM, SEC v. Capital Gains Research (Oct. 17, 1961), Clark Papers, Series II, Box 55, Folder 262.

${ }^{49}$ Capital Gains, 300 F.2d at 747.

${ }^{50}$ Id. at 748. 
The nature of the SEC's allegations becomes murky, however, when the court concedes that there can be no "serious dispute that a relationship of trust and confidence should exist between the adviser and the advised." ${ }^{, 51}$ Does the existence of a fiduciary duty alter when a misleading omission becomes actionable? Apparently not; a fiduciary duty would not necessarily carry a corresponding disclosure obligation. The duty of trust and confidence would be violated only by intentional acts of disloyalty, such as the investment adviser's "failure to disclose that he was being paid to tout a stock." 52 Moore distinguished the SEC's recent Cady, Roberts decision as involving a situation "where inside or so-called confidential information was possessed by one party to the transaction which was not disclosed to the other." ${ }^{53}$ Why that relationship would give rise to an affirmative duty of disclosure, while the relationship of an investment adviser to client would not, is left unclear in Moore's opinion. Query why the presence of an affirmative statement should preclude a parallel fiduciary duty of disclosure.

Given the fragility of the distinctions drawn by Moore, his final rationale for the court's decision may have been the most telling: the need for rulemaking.

[W]hat the SEC would have the court do here is to create a law which Congress has never enacted or a regulation which the SEC has never promulgated which, in effect, would prohibit investment advisers or their employees from purchasing or selling any of the many stocks covered by their services. ${ }^{54}$

${ }^{51}$ Id. at 749.

${ }^{52}$ Id.

${ }^{53} \mathrm{Id}$.

${ }^{54} \mathrm{Id}$. 
The SEC would have disclaimed any inference that its preferred interpretation would sweep as broadly as Moore suggested. The uncertainty over the contours of the SEC's interpretation of $\S 206$, however, only reinforced the need for the specificity that a formal rulemaking could provide. And rulemaking was certainly feasible; just three days after Capital Gains was argued before the appellate judges, the SEC announced a proposal to amend its rules under the Investment Advisors Act to require recordkeeping of securities transactions by investment advisers and their personnel. ${ }^{55}$ If the SEC could require recordkeeping, it could require disclosure.

Judge Waterman also emphasized the need for rulemaking in his memo to his colleagues on the panel. That need was made more acute by Waterman's perception of prevailing industry practice:

I know of no outfit that discloses what it proposes to do about the stock it or its officers may happen to own when it advises you and me what to do with our money. If the SEC wants to go into this field - and perhaps it should - it should get out some rules first. ${ }^{56}$

Despite his agreement with Moore on the need for rulemaking, Waterman concurred only in the result, offering no rationale for his separate position.

Judge Moore’s opinion provoked a dissent from Clark that echoed his shrill tone in Blau. The majority had "endorse[d] and in effect validate[d] a distressingly low standard of business morality,” a result that "top advisers ... not only do not desire, but

${ }^{55}$ SEC, Investment Advisers Act of 1940, Rel. No. 120, Clark Papers, Series II, Box 55, Folder 262.

${ }^{56}$ Memorandum of SRW, SEC v. Capital Gains Research (Oct. 19, 1961), Clark Papers, Series II, Box 55, Folder 262. 
find rather shocking, in the doubt thus cast upon the good faith and loyalty of their profession." ${ }^{57}$ Clark worried about a lemons problem; loyal advisers, argued Clark, needed to be safeguarded "against the stigma of unscrupulous tipsters and touts." 58 Unlike Moore, Clark placed considerable weight on the conclusion that an investment adviser was a fiduciary, whose "first duty ... is loyalty to his beneficiary; if he is engaged in feathering his own nest, he cannot be giving his client that wholly disinterested advice which it his stock in trade to provide." 59

The SEC petitioned for rehearing en banc, which was met by dueling memos from Clark and Moore. ${ }^{60}$ Moore's position was weakened, however, by the position of Waterman, who had only concurred in the original result, apparently because Moore had rejected a number of his suggestions. ${ }^{61}$ That three-way split was sufficient to induce a majority in favor of rehearing en banc to clarify the situation. ${ }^{62}$ Ultimately, only Moore voted to deny the petition. ${ }^{63}$

What followed was a heated debate among the judges of the Second Circuit on the role of statutory interpretation in expanding the boundaries of the securities laws. At oral

${ }^{57}$ Capital Gains, 300 F.2d at 751 (Clark, J., dissenting).

${ }^{58}$ Id. at 752.

${ }^{59}$ Id.

${ }^{60}$ Memorandum of CEC, SEC v. Capital Gains Research (Jan. 17, 1962) \& Memorandum of LPM, SEC v. Capital Gains Research (Jan. 17, 1962), Clark Papers, Series II, Box 55, Folder 262.

${ }^{61}$ Memorandum of SRW, SEC v. Capital Gains Research (Jan. 22, 1962) Clark Papers, Series II, Box 55, Folder 262.

${ }^{62}$ Memorandum of I[rving] R. K[aufman], SEC v. Capital Gains Research (Jan. 22, 1962) \& Memorandum of T[hurgood] M[arshall], SEC v. Capital Gains Research (Jan. 22, 1962), Clark Papers, Series II, Box 55, Folder 262 (both citing three-way result as reason for granting en banc review).

${ }^{63}$ Order Granting Petition for Rehearing In Banc, SEC v. Capital Gains Research (Jan. 23, 1962) Clark Papers, Series II, Box 55, Folder 262. 
argument, Judge Henry Friendly pressed the SEC's counsel on the history of $\S 206$. If $\S$ 206 was modeled on $\S 17(a)$ of the Securities Act, why had Congress omitted the second clause of $\S 17(a)$, which makes it an offense "to obtain money or property by means of any untrue statement of a material fact or any omission to state a material fact necessary in order to make statements made, in light of the circumstances under which they were made, not misleading”? ${ }^{64}$ Judges Waterman and Lumbard wondered why the SEC had not adopted "simple rules" requiring disclosure of the trading alleged to be fraudulent, while Judge Moore complained of the unfairness of not providing the defendant with notice. $^{65}$

Clark, seizing the initiative, launched the first memo to his colleagues just two days after oral argument. ${ }^{66}$ He focused on Friendly’s question about the omission from $\S$ 206 of the language from $\S 17(a)(2)$ of the Securities Act. The rationale for its exclusion, according to Clark, was that it was unnecessary. Investment advisers do not deal directly with their clients, so including a clause relating to obtaining money or property through misrepresentation or omission "would have been a waste of ink and effort." "67 Section 206 was not aimed at common-law deceit of this sort, but rather "to impose fiduciary obligations on those who serve as investment advisers.” ${ }^{68}$ Clark also rejected the argument that the SEC should have promulgated a rule, as "quite frankly judicial

${ }^{64}$ Clark Argument Notes, (Feb. 21, 1962), Clark Papers, Series II, Box 55, Folder 262.

${ }^{65}$ Id.

${ }^{66}$ Supplemental Memo on Rehearing in Banc, CEC, SEC v. Capital Gains Research (Feb. 23, 1962), Clark Papers, Series II, Box 55, Folder 262.

${ }^{67}$ Id. at 3.

${ }^{68}$ Id. at 3-4. 
legislation amending the statute, since the statute is directly prohibitory."69 Clark urged deference:

The SEC is indeed unfortunate in having to bring its regulatory processes before so conservative as court as ours; I wonder if any other federal appellate court would give the Commission a like run-around. I believe we should let it get on with its heavy tasks without the kind of judicial harassment it has here received. ${ }^{70}$

Clark retained his New Deal faith in the expertise of agencies.

Friendly, a prominent proponent of agency rulemaking, ${ }^{71}$ was quick to respond. ${ }^{72}$ He echoed Moore and Waterman's earlier arguments in urging that Congress's 1960 amendment of $\S 206$ to add rulemaking authority in subsection (4) allowed "the SEC [to] accomplish everything it seeks.”73 In Friendly’s view, both a "device, scheme or artifice to defraud" and a "transaction, practice or course of business which operates as a fraud or deceit” if “read in their ordinary sense” were lacking - the defendants did not believe that their sales would depress the price of the securities to the detriment of their customers. ${ }^{74}$ Friendly, like Moore, was looking for badges of intentional fraud. Friendly invoked Blau - handed down by the Supreme Court just the month before - as a caution "against judicial expansion of provision of the securities laws to accomplish objectives believed to

${ }^{69}$ Id. at 4. Clark contrasted $\S 10$ (b). Id. at 5 ("When Congress wanted to make a provision not selfexecuting, but dependent on the adoption of regulations, it knew how to do it expressly, as if did in $\S 10$ (b) of the Securities Exchange Act of 1934”).

${ }^{70}$ Id. at 5.

${ }^{71}$ Henry J. Friendly, The Federal Administrative Agencies: The Need for Better Definitions of Standards (1962).

${ }^{72}$ Memorandum of HJF, SEC v. Capital Gains Research (Feb. 26 1962), Clark Papers, Series II, Box 55, Folder 262.

${ }^{73}$ Id. at 1.

${ }^{74}$ Id. at 2. 
salutary." ${ }^{75} \mathrm{He}$ also scoffed at "the liberal use of such terms as 'fiduciaries' -making people who sell an advisory service sound like trustees of an express trust."76 Friendly urged that the differences between $\S 17(a)$ and $\S 206$ must have had some purpose: "nothing could have been easier than to prohibit the giving of advice which contained ‘any untrue statement of a material fact or any omission' etc."77 Indeed, the SEC had included similar language when it adopted Rules $10 \mathrm{~b}-5$ and $15 \mathrm{c} 1-2{ }^{78}$ Friendly then went on to present an extended history of Congress's amendment to § 206 in 1960, from which he concluded that the power the SEC sought in this case had previously been absent from $\S 206$, but was now available to the agency through rulemaking pursuant to $\S 206(4){ }^{79}$ For Friendly, Congress’s omission of “omission” from $\S 206$ had interpretive consequences, and labeling the investment adviser a fiduciary could not alter that conclusion.

The other Second Circuit judges quickly picked sides. Deference to regulatory agencies had clear ideological overtones and the judges on the Second Circuit were closely split - four of the judges (Lumbard, Waterman, Moore, and Friendly) had been appointed by President Dwight Eisenhower, one had been appointed by Roosevelt (Clark), who had recently been joined by three Kennedy appointees (Irving Kaufman, Paul Hays, and Thurgood Marshall). The remaining judge, John Smith, had been

${ }^{75} \mathrm{Id}$.

${ }^{76}$ Id.

${ }^{77}$ Id. at 3.

${ }^{78}$ Id. at 4.

${ }^{79}$ Id. at 5-7. Friendly pointedly chided the SEC for its failure to research this legislative history "which the SEC has not 'had time' to do in the 15 months this case has been pending." Id. at 1. 
appointed to the district court by Roosevelt before being elevated to the appellate court by Eisenhower. ${ }^{80}$

Clark was quickly joined by Kaufman, Marshall, and Smith in voting to reverse. Kaufman was sharply critical of the notion that the SEC should be required to issue regulations in advance of enforcement:

I cannot subscribe to any notion that the S.E.C. is in any way limited in its enforcement of Section 206 to the issuance of regulations prior to initiation of court action. It has been effectively pointed out that in the area of fraud and deception there can be no all-encompassing regulations. The S.E.C. should not be required to spell out the activities prohibited by the statutes any more than the courts have been made to lay down comprehensive definitions of fraud for common law purposes. $^{81}$

Marshall's brief memo rejected the notion that "[r]egulative statutes [could be] circumscribed by common law principles." ${ }^{82}$ Smith argued that Capital Gains’ trading may have influenced the market price, ${ }^{83}$ or at least that the court should defer to the SEC on this point. "That such purchases and sales had some effect upon the market price of the securities is vigorously asserted by the commission, an agency presumably possessed

\footnotetext{
${ }^{80}$ Federal Judicial Center, History of the Federal Judiciary, supra note 45.

${ }^{81}$ Memorandum of IRK, SEC v. Capital Gains Research, at 2 (Feb. 27, 1962), Clark Papers, Series II, Box 55, Folder 262.

${ }^{82}$ Memorandum of TM, SEC v. Capital Gains Research (Feb. 28, 1962), Clark Papers, Series II, Box 55, Folder 262.

${ }^{83}$ Memorandum of JJS, SEC v. Capital Gains Research, at 2 (Feb. 28, 1962), Clark Papers, Series II, Box 55, Folder 262 ("[I]n each instance of trading by Capital Gains, there is the distinct possibility that the concealed purchase, by reducing the presently available shares, may have adversely affect the price paid by clients of the service. This is a hidden addition to the fee charged the client. In addition, it may well have been true that at least some of the shares sold by Capital Gains were purchased by subscribers or others acting upon the recommendation of Capital Gains ...)”).
} 
of some expertise in the area and whose views should consequently not lightly be brushed

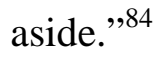

Soon the tide turned, however, with the remaining judges siding with Friendly. Hays was swayed by Friendly's reading of the legislative history, which persuaded him that "Congress did not intend to include in the statute as originally enacted such subtleties as this failure to disclose an adverse interest.. ${ }^{85}$ Waterman wrote at length to explain his disagreement with Moore's original opinion and reasons for voting to affirm. ${ }^{86}$ Waterman disagreed with Moore’s original opinion because he thought “Capital Gains' advice might well affect the price of stock," but Moore declined to delete the opinion's discussion suggesting that a market effect was unlikely. ${ }^{87}$ Waterman nonetheless voted to affirm, disagreeing with Clark on the ethical issues: "I think it inevitable that an honest man honestly advising someone who is paying him for the advice is also entitled to handle his own private affairs as he chooses." ${ }^{88} \mathrm{He}$ was also skeptical of the SEC's understanding of market customs. "The releases of no advisory services known to me, the SEC lawyer to the contrary notwithstanding, discloses in any way what the corporation or its officers or its directors intend to do about the stock they recommend, or what holdings

${ }^{84} \mathrm{Id}$

${ }^{85}$ Memorandum of PRH, SEC v. Capital Gains Research (March 1, 1962), Clark Papers, Series II, Box 55, Folder 262.

${ }^{86}$ Memorandum of SRW, SEC v. Capital Gains Research (March 1, 1962), Clark Papers, Series II, Box 55, Folder 262.

${ }^{87}$ Id. at 2.

${ }^{88}$ Id. 
are owned in that stock by it or them." ${ }^{89}$ Capital Gains trading was not fraudulent, in Waterman's view, "but instead, at the worst ... a device by which Capital Gains could

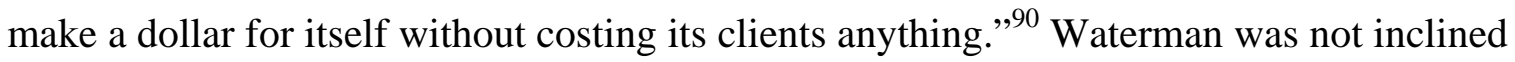
to defer to the SEC on questions of practice in the securities industry. Given this "common practice" he concluded "that the stock transactions of the defendant were not clearly fraudulent or clearly a breach of trust by it to its subscribers." 91 Accordingly, "this proceeding ... should not have been brought until after the promulgation of a rule."92 The day after Waterman circulated his memo, Moore wrote tersely, "I vote to affirm."93 With the court split 4-4, Lumbard, the chief judge weighed in, voting to affirm. ${ }^{94}$

Only after all the votes were in was the SEC heard from again. Judge Friendly had inquired of the SEC's counsel why there was no analogue to $\S 17(a)(2)$ of the Securities Act in § 206 of the Investment Advisers Act. The SEC’s response to Friendly’s

${ }^{89}$ Id. See also id. at 4 ("I think what the defendant did in this case is less odious than the acts committed by losing defendants in the earlier cases involving parallel sections of the security acts. One reason for my belief is that all large investment advisers as well as large brokers and dealers regularly trade in the securities about which they advise or in which they deal. Secondly, it seems to be the custom of the trade for even brokers merely to state they 'may or may not have a position in the securities which they recommend." ). Indeed, Waterman believed that purchasing ahead of the recommendation was validation that the recommendation was bona fide: "a purchaser of an advisory service would not think much the advisory service or the person running it if the advisory service personnel would not buy if the recommendation was to buy.” Id. at 2.

${ }^{90}$ Id. at 1.

${ }^{91} \mathrm{Id}$. at 4.

92 Id. at 6.

${ }^{93}$ Memorandum of LPM, SEC v. Capital Gains Research (March 1, 1962), Clark Papers, Series II, Box 55, Folder 262.

${ }^{94}$ Memorandum of JEL, SEC v. Capital Gains Research (March 7, 1962), Clark Papers, Series II, Box 55, Folder 262. 
question was essentially, "We don’t know."95 Oddly enough, this response failed to sway any of the judges in the majority. Nor did Clark’s personal lobbying of Hays in an effort to bring him back to the side of the Democratic appointees. ${ }^{96}$

All that remained was the drafting of a new opinion. This was a somewhat delicate matter as Moore's initial effort had drawn little support from his colleagues. Moore returned to the drawing board with instructions from Lumbard to incorporate the views of Friendly in his opinion. ${ }^{97}$ Moore cut the objectionable discussions relating to the standard for an injunction and the materiality of the alleged omissions. ${ }^{98}$ He added Friendly's rendition of the legislative history, ${ }^{99}$ as well as Blau's caution "against the excessive judicial expansion of provisions of the securities laws to accomplish objectives believe to be salutary."100

Clark’s new dissent praised the securities laws extravagantly: “this legislation was brilliantly successful in responding to a genuine social need. It is a prime demonstration of the capacity of a democratic government to meet a social crisis skillfully and

${ }^{95}$ Letter of David Ferber, Associate General Counsel of the SEC to the Second Circuit, SEC v. Capital Gains Research Bureau (March 6, 1962), Clark Papers, Series II, Box 55, Folder 262.

${ }^{96}$ Note from Charles E. Clark to Paul Hays (March 28, 1962), Clark Papers, Series II, Box 55, Folder 262 (“Perhaps my greatest trouble is your reliance on H.J.F.'s memo-which I'm afraid I must hold the most specious of the lot. There is just nothing to rest on in his excursions into legisl. historyunfortunately a smoke screen.”).

${ }^{97}$ Memorandum of JEL, SEC v. Capital Gains Research (March 7, 1962), Clark Papers, Series II, Box 55, Folder 262.

${ }^{98}$ SEC v. Capital Gains Research Bureau, Inc., 306 F.2d 606, 608 ( $2^{\text {nd }}$ Cir. 1962) (en banc).

${ }^{99}$ Id. at $609-611$.

${ }^{100}$ Id. at 609 (citing Blau v. Lehman, 368 U.S. 403 (1962)). 
positively." ${ }^{101}$ The majority’s opinion, however, “comes as a real shock” that would "scuttle the last of these highly useful statutes and leave it as but a shell." ${ }^{102}$ The securities laws, urged Clark, should be "liberally construed to effectuate the broad remedial purpose of the acts.”103 Clark also criticized the majority's reliance on the 1960 amendments to $\S 206$ : “To determine the intention of Congress of 1940 we must look backwards from the date of passage, not forwards." ${ }^{104}$ And he rejected the suggestion that the SEC could reach the defendants' conduct through rulemaking: "the hope of regulation which will require Capital Gains to meet appropriate fiduciary standards not contained in the statute is illusory indeed.”105

Clark forwarded the opinions to Louis Loss, ${ }^{106}$ who was "literally appalled" by the majority opinion. ${ }^{107}$ Loss could "hardly think of anything more low-down than a paid investment adviser's using his influence with his clients to feather his own nest." ${ }^{\text {108 }}$ Clark took comfort in Loss's endorsement of his position, but soon enough he would get an even more authoritative vote of confidence. ${ }^{109}$

${ }^{101}$ Capital Gains, 306 F.2d at 611-612 (Clark, J., dissenting).

${ }^{102}$ Id. at 612.

${ }^{103}$ Id. at 614.

${ }^{104}$ Id. at 615.

${ }^{105}$ Id. at 619.

${ }^{106}$ Letter of Charles E. Clark to Professor Louis Loss, (July 31, 1962), Clark Papers, Series II, Box 55, Folder 262.

${ }^{107}$ Letter of Louis Loss to Charles E. Clark, (December 17, 1962), Clark Papers, Series II, Box 55, Folder 262.

${ }^{108} \mathrm{Id}$.

${ }^{109}$ Capital Gains was closely followed back in the Second Circuit, with District Court Judge William Timbers, formerly General Counsel at the SEC, providing Clark with updates on the case's progress in the Supreme Court. See Handwritten Note from William H. Timbers to Judge Clark, (9/20/--) (advising Clark that SEC had authorized certiorari petition and was awaiting approval from the Solicitor 


\section{The Supreme Court}

After the knock-down, drag-out fight in the Second Circuit, the course of Capital Gains in the Supreme Court was surprisingly tame. Five justices voted to grant certiorari, ${ }^{110}$ with Chief Justice Warren expressing concern that the Second Circuit "ha[d] gone overboard in its opinion and gives aid + comfort to sharp dealers."111 The result was lopsided, with only Justice John Marshall Harlan voting to affirm.

Justice Arthur Goldberg was assigned the opinion. Goldberg’s initial circulation did not emphasize the investment adviser's status as a fiduciary. ${ }^{112}$ The language relating to fraud by fiduciaries was added in response to a letter from Justice Byron White, who suggested that,

the treatment might be stronger if the investment adviser may be looked upon as a fiduciary ... and if the content of fraud and deceit as applied to a fiduciary is considered. ... If the fiduciary has a settled duty to disclose and if his failure to do so is termed fraudulent, there was little need for Congress in dealing with the fiduciary in the Investment Advisers Act to speak of anything but fraud in order to reach a failure to disclose a material fact or at the very least a conflict of interest. $^{113}$

General); Memo from WHT to CEC, (12/3/1962) (advising Clark that SEC had filed certiorari petition); Letter from William H. Timbers to Hon. Charles E. Clark (1/21/1963) (advising Clark that certiorari had been granted), Charles E. Clark Papers, Series II, Box 55, Folder 262.

${ }^{110}$ SEC v. Capital Gains Research Bureau, No. 42, Docket Sheet (January 18, 1963) ("Grant: Goldberg, White, Douglas, Black, C.J.”), Earl Warren Collection, Box 378, Library of Congress.

${ }^{111}$ Handwritten Notes, Cert. Memo, SEC v. Capital Gains Research Bureau, No. 42 (Undated), Earl Warren Collection, Box 247, Library of Congress.

${ }^{112}$ SEC v. Capital Gains Research Bureau, First Circulation (Nov. 27, 1963), Arthur Goldberg Collection, Box 17, Folder 3, Northwestern University Library.

${ }^{113}$ Letter from Byron R. White to Arthur Goldberg, Re: No. 42 - SEC v. Capital Gains Research Bureau (December 2, 1963), Arthur Goldberg Collection, Box 17, Folder 3, Northwestern University Library. 
Pritchard:

In other words, the Second Circuit majority had gotten the case wrong not because it restricted $\S 206$ to common law fraud, but rather, because material nondisclosure by a fiduciary was fraud per se. If the investment adviser was treated as fiduciary, the common law (or at least equity) did not need to be stretched to treat non-disclosure as fraudulent. ${ }^{114}$ No specific mention of omissions in $\S 206$ would be required, nor would rulemaking.

Goldberg quickly latched on to White's suggestion, revising his opinion to emphasize the relation between fiduciary status and fraud:

Nor is it necessary, in a suit against a fiduciary, which Congress recognized the investment adviser to be, to establish all the elements required in a suit against a party to an arms-length transaction. Courts have imposed on a fiduciary an affirmative duty of 'utmost good faith, and full and fair disclosure of all material facts. $^{, 115}$

Notable here is the lack of analysis underlying the conclusion that investment advisers are fiduciaries. ${ }^{116}$ Notwithstanding Goldberg's breezy treatment of this issue, the holding

White was relying upon the research of his law clerk, Rex Lee, as the basis for his suggestions. See REL, Memo, No. 42 OT 1963, SEC v. Capital Gains Research Bureau, Concealment by a fiduciary as fraud, Byron R. White Collection, Box 35, Folder 6, Library of Congress ("Early cases in this Court .. indicate by dictum that a fiduciary or one who occupies a special relation to another, commits fraud when he fails to disclose a material fact.”). Lee would come to play a role again in the development of insider trading law, when as Solicitor General, he would urge the Supreme Court to reverse the SEC's broad view of tipper-tippee liability. See Dirks v. SEC, 463 U.S. 646, 648 (1983).

114 On the status of investment advisers as fiduciaries, see Laby, supra note 38, at 1066-1078.

115 SEC v. Capital Gains Research Bureau, Second Circulation, at 14 (Dec. 4, 1963), Arthur Goldberg Collection, Box 17, Folder 3, Northwestern University Library (citations omitted).

116 James R. Ukropina, The Investment Advisers Act and the Supreme Court's Interpretation of its Anti-Fraud Provisions, 37 S. Cal. L.Rev. 359, 362 (1964) (“A more relevant inquiry from the outset might have been to ask whether or not a subscriber to a market letter costing \$18 a year should be considered to have entered into a fiduciary relationship when he pays his subscription price. Further discussion of this issue would seem warranted since disputes still exist in tort law as to the nature of many relationships and the consequential necessity for disclosure”). 
here would become the germ of the insider trading prohibition that the Court would later recognize under § 10(b).

Having used equity to free $\S 206$ from the common law constraints that the lower courts had imposed on it, Goldberg announced an interpretive canon that was surely music to William Cary’s ears: “Congress intended the Investment Advisers Act of 1940 to be construed like other securities legislation enacted for the purpose of avoiding frauds, not technically and restrictively, but flexibly to effectuate its remedial purposes." ${ }^{117}$ Having adopted this flexible/remedial interpretive canon from Clark’s dissent, Goldberg brushed aside the differences between § 17(a) of the Securities Act and $\S 206$ of the Investment Advisers Act: "Congress, in enacting [§ 206] ... deemed a specific proscription against nondisclosure surplusage." ${ }^{118}$ Clark's ultimate victory over Friendly was secured; it seemed that statutory text could be overcome by the flexible/remedial interpretive canon. It remained to be seen whether that canon would be generally applied when interpreting the securities laws.

\section{The influence of Capital Gains}

Capital Gains' interpretive approach would find fertile ground in the Second Circuit. Clark died in 1963 - just four days after Capital Gains was handed down by the Supreme Court ${ }^{119}$ - but other judges took up the SEC's cause. Four years later, in SEC V.

\footnotetext{
${ }^{117}$ Capital Gains, 375 U.S. at 195 (citations and quotations omitted).

${ }^{118}$ Id. at 198-199.

${ }^{119}$ Federal Judicial Center, History of the Federal Judiciary, supra note 45.
} 
Texas Gulf Sulfur, Judge Waterman would write for the majority of the Second Circuit validating the SEC’s expansive reading of $\S 10(\mathrm{~b})$ of the Exchange Act. ${ }^{120}$ Capital Gains would be cited by the Texas Gulf Sulfur majority for the proposition that even negligent insider trading would be unlawful. ${ }^{121}$ Capital Gains was cited not only for that particular proposition of law, but also for the flexible/remedial interpretive presumption: "the securities laws should be interpreted as an expansion of the common law ... to effectuate the remedial design of Congress.”122 Friendly was forced by the precedential weight of Capital Gains to concede that negligence would suffice in an SEC suit seeking injunctive relief, but he fought a rearguard action (which he would eventually win) against allowing suits for money damages without a showing of scienter. ${ }^{123}$ Lumbard and Moore found themselves in dissent, forced to give lip service to Capital Gains' flexible/remedial interpretive canon, but refusing to follow it to its logical conclusion. ${ }^{124}$ Nonetheless, Chairman Cary's broad approach to insider trading in Cady, Roberts now had been validated by the most important circuit court for securities law.

The Supreme Court's first citation to Capital Gains was equally promising for the SEC. Justice Blackmun, writing for the Court in Affiliated Ute Citizens v. United States, cited Capital Gains for the proposition that "Congress intended securities legislation enacted for the purpose of avoiding frauds to be construed 'not technically and

\footnotetext{
${ }^{120} 401$ F.2d 833 ( $2^{\text {nd }}$ Cir. 1968) (en banc).

${ }^{121} \mathrm{Id}$. at 855 .

$122 \mathrm{Id}$.

123 Texas Gulf Sulfur, 401 F.2d at 864, 868 (Friendly, J., concurring).

${ }^{124}$ Texas Gulf Sulfur, 401 F.2d at 870 (Moore, J., dissenting, joined by Lumbard, C.J.).
} 
restrictively, but flexibly to effectuate its remedial purposes."’125 The flexible/remedial interpretation in Affiliated Ute allowed the Court to excuse proof of reliance under Rule 10b-5 in cases "involving primarily a failure to disclose."126 Thus, the Supreme Court took another step toward validating an insider trading prohibition under the rubric of Rule 10b-5.

Headwinds soon arose for the flexible/remedial principle, however, with the appointment of Lewis Powell to the Supreme Court. ${ }^{127}$ The SEC cited Capital Gains flexible/remedial principle in its brief in United Housing Foundation, Inc. v. Forman. ${ }^{128}$ Powell ignored Capital Gains in drafting his majority opinion; it is cited by Justice Brennan in his dissent. ${ }^{129}$ The case was cited again by the SEC the following term as supporting a negligence standard for $\S 10(\mathrm{~b})$ of the Exchange Act. ${ }^{130}$ Powell, again writing for the Court, rejected flexible interpretation of the securities laws in light "of the language of $\S 10(\mathrm{~b})$, which so clearly connotes intentional misconduct.” ${ }^{131}$ Justice

${ }^{125} 406$ U.S. 128, 151 (1972). Justice Douglas asserts the same proposition in Superintendent of Insurance v. Bankers Life and Casualty Co., 404 U.S. 6, 12 (1971) ("Section 10(b) must be read flexibly, not technically and restrictively.”), but he provides no citation.

${ }^{126}$ Affiliated Ute, 406 U.S. at 153.

${ }^{127}$ Powell was only recently appointed to the Court at the time Affiliated Ute was decided and he did not participate in the decision. Id. at 157. On Powell's resistance to the SEC's efforts to expand the boundaries of the securities law, see generally A.C. Pritchard, Justice Lewis F. Powell, Jr. and the CounterRevolution in the Federal Securities Laws, 52 Duke L.J. 841 (2003).

${ }^{128}$ Brief for the Securities and Exchange Commission as Amicus Curiae, United Housing Foundation, Inc. v. Forman, Nos. 74-157 and 74-647, at 10-11.

${ }^{129}$ United Housing Foundation, Inc. v. Forman, 421 U.S. 837, 867-868 (1975) (Brennan, J., dissenting).

${ }^{130}$ Ernst \& Ernst v. Hochfelder, 425 U.S. 185, 200 (1976).

${ }^{131}$ Id. at 201. 
Blackmun, in dissent, cited Capital Gains and his own opinion in Affiliated Ute for the principle of flexible/remedial interpretation. ${ }^{132}$

A pattern was set. The SEC would cite Capital Gains in support of a broad interpretation of the securities laws, and the Supreme Court - under the influence of Justice Powell - would brush it aside, insisting that the language of the statute would not support the interpretation. ${ }^{133}$ The conflict over this interpretive principle between the conservative and liberal blocs of the Court would come to a head in two cases from the October 1979 term.

The first case, Chiarella v. United States, ${ }^{134}$ laid the groundwork for the Court's insider trading jurisprudence under $\S 10(\mathrm{~b})$. Justice Powell, writing for the Court, construed Cady, Roberts and Texas Gulf Sulfur and its progeny in the Second Circuit narrowly, fitting those decisions into the common law framework that Powell favored. ${ }^{135}$ More gallingly to Blackmun, Powell read Affiliated Ute as imposing "liability premised upon a duty to disclose arising from a relationship of trust and confidence between parties to a transaction." ${ }^{136}$ After reading Powell's draft opinion, Blackmun wrote to his law clerk, "I think it advisable, also, to point out, if it is the case, that Justice Powell is giving a narrowing interpretation to Affiliated Ute Citizens. I wrote that opinion, and I certainly

\footnotetext{
${ }^{132}$ Id. at 217. Blackmun had also cited Capital Gains the previous term in dissent. See Blue Chip Stamps v. Manor Drug Stores, 421 U.S. 723, 762 (1975) (Blackmun, J., dissenting).

${ }^{133}$ See, e.g., Santa Fe Industries, Inc. v. Green, 430 U.S. 462, 475 \& n. 15 (1977) (distinguishing Capital Gains on the ground that the case involved deceptive non-disclosure).

${ }^{134} 445$ US 222 (1980).

${ }^{135}$ A.C. Pritchard, United States v. O’Hagan: Agency Law and Justice Powell's Legacy for the Law of Insider Trading, 78 B.U. L.Rev. 13 (1998).

${ }^{136}$ Chiarella, 445 U.S. at 230.
} 
don’t want it unduly narrowed." 137 In his first draft of his dissent, Blackmun wrote "It seems to me that with its decision in this case the Court continues its emasculation of $\S$ 10(b) ... I, of course, have been unsuccessful in my attempts to stop this trend."138 This defeatist language did not make it into the final version of Blackmun's dissent, but the published version did little to disguise his bitterness.

The Court continues to pursue a course, charted in certain recent decisions, designed to transform $\S 10$ (b) from an intentionally elastic "catchall” provision to one that catches relatively little of the misbehavior that all too often makes investment in securities a needlessly risky business for the uninitiated investor. ... [T]he Court fails even to attempts a justification of its ruling in terms of the purposes of the securities laws, or to square that ruling with the long-standing but now much abused principle that the federal securities laws are to be construed flexibly rather than with narrow technicality. ${ }^{139}$

Blackmun argued that his Affiliated Ute opinion gave "strong support to the principle that a structural disparity in access to material information is a critical factor under Rule 10b5 in establishing a duty either to disclose the information or to abstain from trading." This is the parity of information theory that the SEC had been pushing - successfully - in the Second Circuit. Under Capital Gains flexible interpretive approach, Affiliated Ute probably would have been read as Blackmun favored. The Supreme Court, however, was now under the sway of Justice Powell in the field of securities law. Powell favored the technical and restrictive interpretation rejected by Capital Gains, notwithstanding the

${ }^{137}$ Memo from HAB to Mark, No. 78-1202 - Chiarella v. United States (2/4/80), Harry Blackmun Papers, Library of Congress.

${ }^{138}$ Id.

${ }^{139}$ Chiarella, 445 U.S. at 246-247 (Blackmun, J., dissenting) (citations omitted).

${ }^{140}$ Id. at 251. 
concessions he made to Capital Gains' equitable notions of fraud in framing the more limited insider trading prohibition under $§ 10(b)$ in Chiarella.

The second securities case of the term, Aaron v. SEC, ${ }^{141}$ rejected Capital Gains' interpretive principle even more emphatically. Aaron raised the question of the state of mind required under $\S 10(\mathrm{~b})$ in an SEC enforcement action seeking injunctive relief. Again the SEC urged the Court to follow Capital Gains and not require a showing of intent. ${ }^{142}$ The Court demurred, distinguishing Capital Gains on the grounds that $\S 206$ ’s language and legislative history differed from $\S 10(\mathrm{~b})$ 's. ${ }^{143}$ Moreover, the Aaron Court was explicit in rejecting Capital Gains' flexible/remedial interpretive principle: "generalized references to the remedial purposes of the securities laws will not justify reading a provision more broadly than its language and the statutory scheme reasonably permit.” ${ }^{144}$ Blackmun was again in dissent, unpersuaded by the Court's attempt to distinguish Capital Gains. $^{145}$

Not much was left of Capital Gains at this point, but Powell wanted to go further, completely purging it from the judicial lexicon. The following term, in a case involving the definition of a sale under the Securities Act, ${ }^{146}$ Powell offered to join Chief Justice Burger's opinion for the majority if the Chief would refrain from citing

\footnotetext{
141446 U.S. 680 (1980).

142 Id. at 693.

143 Id. at 694.

${ }^{144}$ Id. at 695.

145 Id. at 703, 705-710 (Blackmun, J., dissenting).

${ }^{146}$ Rubin v. United States, 449 U.S. 424 (1981).
} 
the 1963 case of SEC v. Capital Gains Research Bureau, quoting language to the effect that federal security laws must be construed "not technically and restrictively but flexibly to effectuate [their] remedial purposes."

A number of more recent decisions, for example, Hochfelder relied on by your opinion, have looked primarily to the plain language of the securities acts. These are highly technical and well drawn statutes, and as you make clear by the remainder of your opinion this case falls within the explicit language of §§2(3) and 17(a). Thus, the quote from Capital Gains Research Bureau is unnecessary and perhaps could be viewed as undercutting to some extent your reliance on the statutory language itself. ${ }^{147}$

Chief Justice Burger excised the offensive language from Capital Gains. ${ }^{148}$

Powell had won a minor victory, but he had not yet put a stake through the heart of Capital Gains’ flexible/remedial principle. Two terms later, in a case in which Powell did not participate, Justice Thurgood Marshall cited Capital Gains. ${ }^{149}$ And the term after Powell retired, Blackmun referred to the flexible/remedial principle in interpreting $\S$ 12(a)(1) of the Securities Act. ${ }^{150}$ Blackmun went on, however, to ground the decision in the statutory language, rejecting the broader interpretation adopted by the court of appeals. After that passing reference, nearly fifteen years would go by before Justice Stevens would cite Capital Gains for the flexible/remedial interpretive principal, in a

\footnotetext{
${ }^{147}$ Letter from Justice Lewis F. Powell, Jr., to Chief Justice Warren E. Burger (Jan. 8, 1981), Powell Archives, Washington \& Lee Law Library.

${ }^{148}$ Letter from Chief Justice Warren E. Burger to Justice Lewis F. Powell, Jr. (Jan. 8, 1981) Powell Archives, Washington \& Lee Law Library.

${ }^{149}$ Herman \& MacLean v. Huddleston, 459 U.S. 375, 389 (citing Capital Gains) and id. at 391 (Powell not participating).

${ }^{150}$ Pinter v. Dahl, 486 U.S. 622, 653 (1988)
} 
case involving insider trading. ${ }^{151}$ Stevens’ invocation did not mark a revival; Capital Gains has not been cited by the Supreme Court since.

\section{Conclusion}

Capital Gains made two important innovations in the Supreme Court's securities jurisprudence. The first was that a statutory anti-fraud provision could incorporate, without specific reference, duties of disclosure owed by fiduciaries to their beneficiaries. The second was the interpretive principle that the securities laws are to be flexibly construed to achieve their remedial objectives. The first contribution has survived as part of insider trading law, accepted unreservedly by Justice Blackmun in Affiliated Ute and more grudgingly by Justice Powell in Chiarella. The second contribution has not fared as well despite Justice Blackmun's adoption of it in Affiliated Ute. Interpretation of the securities laws was cabined by the Supreme Court, primarily Justice Powell, as the Court resisted the efforts of the SEC and private plaintiffs to expand their reach. Powell's successors on the Court have been no more generous with their interpretation. The flexible/remedial principle survives - if it does survive - only as a ritual incantation before proceeding to parse precisely the terms of the statute at issue.

Why has the flexible/remedial principle fared so poorly of late? The easy answer is that the Supreme Court has become more conservative since its heady Warren Court days. A more critical answer is that the principle lacks analytical content. The principle could be rephrased simply as "SEC wins" and it would be just as useful. It does not

${ }^{151}$ SEC v. Zandford, 535 U.S. 813, 819 (2002). 
provide a court with any guidance in attempting to discern the outer boundaries of the SEC's authority. Unless a court is willing to cede the SEC unlimited authority, "flexible" interpretation offers no help in deciding concrete cases.

Statutory language, the "technical" tool of choice for Justice Powell and his successors, offers something tangible, something judicial, for a judge to work with. To be sure, policy preferences may be lurking just below the surface. That preference for grounding results in statutory text may be unsatisfying for those dissatisfied with the reluctance of Congress to provide meaningful guidance in controversial areas such as insider trading. And it would surely be unsatisfying for New Dealers like Charles Clark and William O. Douglas, who put their faith in the expertise of administrative agencies like the SEC. For the foreseeable future, however, do not expect the Supreme Court to revive Capital Gains as a substitute for legislation and rulemaking in the field of securities law. 